\title{
Analisis Pandemi Covid-19 Dalam Perspektif Collective Action (Studi Kasus: Kecamatan Cariu Kabupaten Bogor)
}

\author{
1 Anton Hilman \\ ${ }^{2}$ Ramadhan Pancasilawan
}

\author{
${ }^{1}$ Universitas Padjajaran, anton19004@mail.unpad.ac.id \\ ${ }^{2}$ Universitas Padjajaran, Ramadhan.pancasilawan@unpad.ac.id
}

\begin{abstract}
In the midst of the Covid-19 pandemic, many people are affected by health, economic and social aspects. With the existence of a government policy regarding large-scale social restrictions to break the chain of the virus but it creates new problems in the community. Starting from the existing problems, social actions or social activities can help overcome covid-19. Collective actions taken by the community in the midst of the Covid-19 pandemic are small things that can help overcome problems in the community. Community collective action in the form of preventive, curative and promotive actions. Collective preventive action is to distribute masks, hand sanitizers, and spray disinfectants. Collective action in a curative manner, namely by providing social assistance, working on the waqf land and fish ponds, then the visiting neighbor program. Collective action in a promotive manner, namely by disseminating information related to Covid-19 to the public and also by making a handbag made by a cariu student forum from betel leaf. Collective action fosters empathic norms and attitudes in society. Collective action works best when free riding is avoided. The large number of illegal riders made the collective action not maximal. Collective action will also run well if data data and information are well available. Collective action can work well if social capital in the form of a sense of belonging, human values, and empathy grows in individuals.
\end{abstract}

Keywords: Governance, Collective Action, Local Government, Covid-19.

\section{Pendahuluan}

Coronavirus adalah sekumpulan virus dari subfamili Orthocronavirinae dalam keluarga Coronaviridae dan ordo Nidovirales. Coronavirus adalah kumpulan virus yang bisa menginfeksi sistem pernapasan. Pada banyak kasus, virus ini hanya menyebabkan infeksi pernapasan ringan, seperti flu.(Covid-, 2020) Namun, virus ini juga bisa menyebabkan infeksi pernapasan berat, seperti infeksi paru-paru (pneumonia). Selain virus SARS-CoV-2 atau virus Corona, virus yang juga termasuk dalam kelompok ini adalah virus penyebab Severe Acute Respiratory Syndrome (SARS) dan virus penyebab Middle-East Respiratory Syndrome (MERS). Meski disebabkan oleh virus dari kelompok yang sama, yaitu coronavirus, COVID19 memiliki beberapa perbedaan dengan SARS dan MERS, antara lain dalam hal kecepatan penyebaran dan keparahan gejala.

Dalam kondisi saat ini, virus corona bukanlah suatu wabah yang bisa diabaikan begitu saja. Jika dilihat dari gejalanya, orang awam akan mengiranya hanya sebatas influenza biasa, tetapi bagi analisis kedokteran virus ini cukup berbahaya dan mematikan. Saat ini di tahun 2020, perkembangan penularan virus ini cukup signifikan karena penyebarannya sudah mendunia dan seluruh negara merasakan dampaknya termasuk Indonesia.

Maraknya penyebaran virus corona covid-19 telah menyebabkan terjadinya perubahan sosial di masyarakat yang salah satunya didukung dengan teknologi komunikasi. Masyarakat dituntut bisa dan terbiasa. Perubahan terjadi pada cara berkomunikasi, cara berpikir, dan cara berperilaku manusia. Sebenarnya perubahan sosial ini lantaran pandemi corona covid-19 ini sejalan dengan perkembangan teknologi komunikasi melalui digitalisasi yang tanpa kita sadari sudah merealisasikannya. 
Menurut Stephen W. Littlejohn dalam bukunya Theories of Human Communication (Sendjaja, 2014), terdapat tiga pendekatan dalam berkomunikasi antar-manusia. Yang pertama adalah Pendekatan scientific (ilmiah-empiris). Umumnya, pendekatan ini berlaku di kalangan ahli ilmu eksakta. Cara pandang yang menekankan unsur objektivitas dan pemisahan antara known (objek yang ingin diketahui dan diteliti) serta knower (subjek pelaku atau pengamat). Lalu, ada Pendekatan Humanistic (Humaniora Interpretatif). Ini merupakan pendekatan dengan cara pandang yang mengasosiasikan dengan prinsip subjektivitas. Manusia mengamati sikap dan perilaku orang-orang di sekitarnya, membaur dan melibatkan diri secara aktif dalam kehidupan orang-orang di lingkungannya. Yang ketiga adalah Pendekatan Social Sciences (Ilmu Sosial). Ini merupakan gabungan dari pendekatan scientific dan humanistic di mana objek studinya adalah kehidupan manusia, termasuk di dalamnya memahami tingkah laku manusia. Tampak jelas bahwa manusia membutuhkan kesempatan secara langsung untuk berpartisipasi aktif dalam kehidupan di sekitarnya. Di sinilah terlihat kondisi pandemic corona Covid-19 jauh dari ideal hubungan manusia secara humanis.

Perlu direnungkan pembatasan social bersekala besar (PSBB) membuat masyarakat enggan untuk melakukan aktivitas diluar rumah. Ini menyebabkan perubahan sikap dan kondisi manusia yang berubah dari kebiasaan lamanya. Perubahan tersebut tidak secara instan, akan tetapi memerlukan waktu yang lama. Perubahan tersebut dirasakan oleh masyarakat Kecamatan Cariu Kabupaten Bogor, dengan adanya PSBB tersebut.

Dari perubahan itu muncul dampak secara ekonomi dan ekonomi. Dari aspek ekonomi, penurunan daya beli masyarakat berdampak pada penurunan ekonomi di Indonesia, pertumbuhan ekonomi Indonesia pada kuartal I hanya 2,97 \% terendah dari 2001(databok.co.id). Penurunan ini menunjukan bahwa dampak dari Covid-19 sangat harus diwaspaiadi. Dari aspek social, kondisi masyarakat yang tidak banyak melakukan aktivitasnya menjadikan kurangnya interaksi secara langsung.

Mancur Olson di tahun 1965 menulis tentang teori aksi kolektif. Sampai hari ini, teori Olson banyak digunakan di berbagai bidang studi, termasuk politik dan ekonomi. Logika collective action Mancur Olson Jr menyatakan bahwa kerjasama hanya dapat terjadi apabila setiap individu yang terlibat didalamnya memperoleh manfaat yang lebih besar dari biaya yang dikeluarkan, hitungan untung dan rugi individu lebih penting.(Foys, 2014). Pengertian tindakan collective action memiliki pengertian yang cukup luas menurut beberapa ahli, diantaranya Wright, Taylor, \& Moghaddam (1990) yang memberikan pengertian bahwa collective action merupakan tindakan yang dilakukan sekelompok individu dengan tujuan untuk memperbaiki kondisi dari kelompoknya. Selain memperbaiki kondisi, tindakan collective action juga mampu meningkatkan status kelompok tersebut dari kelompok yang lain (Tajfel, \& Turner, 1979).

Zomeren dan Louis (2017) menambahkan bahwa kesamaan budaya dari suatu kelompok diklaim sebagai latar belakang dari munculnya tindakan yang dilakukan kelompok secara massal. Dapat dikatakan pula bahwa tindakan collective action merupakan gabungan dari dinamika gender, etnis, agama atau paradigma kelompok yang berbeda dengan kelompok lainnya (Jasper, 2017). Bamberg, Rees, \& Seebauer (2015) menyebutkan didalam collective action ada pertimbangan mewujudkan keadaan salah satunya the collective efficacy pathway / Jalur efikasi kolektif. Hal ini merujuk pada keyakinan individu menghadapi tekanan-tekanan yang berasal dari lingkungan sosialnya. Dengan keyakinan diri tersebut, individu akan memberikan respon untuk ikut serta dalam tindakan yang akan dilakukan kelompoknya atau tidak (Willer, 2009). Dengan kata lain, individu akan memproses segala informasi dari lingkungan yang kemudian memberikan motivasi untuk keikutsertaannya atau tidak terhadap tindakan kolektif tersebut. Kesesuaian dengan permasalahan yang akan diteliti ini adalah bahwa dalam menentukan suatu perilaku tersebut maka individu akan mempertimbangkan dari 
kelompoknya. Seperti contoh masyarakat yang ingin melakukan aksi penolakan terhadap kebijakan pemerintah mengenai relokasi maka akan melihat pula respon dari kelompok masyarakatnya.

Charles Tilly (1978) menyebutkan ada empat elemen munculnya collective action yaitu pertama kepentingan (Interest), dimana aspek ini mencakup keuntungan dan kerugian yang diakibatkan dari interaksi dalam kelompok atau kelompok lain sesuai pada kepentingan dengan tindakan yang akan dilakukan untuk mencapainya. Pada aspek ini individu dalam kelompok juga akan mempersepsikan relevan atau tidak antara dirinya dengan kelompok. Kedua, organisasi (organization), dimana aspek ini mencakup pada struktur didalam kelompok sehingga ada pengaruh tekanan dalam melakukan tindakan untuk mencapai tujuan yang dikehendaki bersama. Didalamnya pun akan diketahui komitmen keterlibatan individu didalam kelompok tersebut. Ketiga, yaitu mobilisasi (mobilization), dimana aspek ini mencakup pada ketersediaan sumber daya sebagai fasilitas penunjang terlaksananya tindakan kolektif yang dilakukan kelompok, seperti kendaraan, jumlah anggota yang terlibat, atau bahkan lebih ekstremnya adalah persenjataan. Keempat, yaitu peluang (opportunity), dimana aspek ini mencakup peluang yang tercipta dari hubungan interaksi antara anggota dalam kelompok atau dengan kelompok lain untuk mengetahui peluang sebelum melakukan tindakan.

Dengan demikian, tulisan ini ingin menganalisis fenomena kehidupan masyarakat di Indonesia di tengah Pandemi Covid-19 berdasarkan pada perspektif collective action.

\section{Metode Penelitian}

Metode yang digunakan dalam artikel ilmiah ini dengan menggunakan kualitatif deskriftif. Dimana penulis menggambarkan situasi dan kondisi yang ada di masyarakat Kecamatan Cariu Kabupaten Bogor dengan mengkorelasikannya dengan teori collective action. Dengan sumber data sekunder yang berasal dari media elektronik dan pengamatan secara langsung diwilayah terdampak Covid-19. Penulis juga mengamati percakapan masyarakat terkait permasalahan di tengah wabah Covid-19 yang berkaitan dengan tindakan kelompok masyarakat dalam membenahi kondisi social dan ekonomi masyarakat.

\section{Hasil dan Pembahasan}

Pandemic Covid-19 merupakan wabah yang menyerang diseluruh dunia dan tidak mengenal usia. Dampak yang ditimbulkan dari pandemi ini yaitu Kesehatan, ekonomi dan sosial. Dampak tersebut sangat dirasakan bagi masyarakat khususnya di kecamatan Cariu. Collective action yang dilakukan masyarakat Kecamatan Cariu ini dikarenakan wabah covid19 tersebut membuat masyarakat terkena dampak. Dari berbagai aspek masyarakat melakukan Tindakan kolektif atau aksi nyata dalam penanggulangan wabah Covid-19.

\section{Aspek Kesehatan}

Kecamatan Cariu merupakan zona hijau yang ada diwilayah Kabupaten Bogor dari dampak covid-19. Akan tetapi tidak menutup kemungkinan sosialisasi dan memberikan kewaspadaan kepada masyarakat kecamatan Cariu harus dilakukan. Aksi nyata yang tergerak dari berbagai element masyarakat ikut berjuang dalam menuntaskan wabah covid-19.

Dari segi Kesehatan banyak masyarakat Kecamatan Cariu belum memahami apa yang disebut dengan covid-19 atau corona virus tersebut. Maka dari itu forum mahasiswa cariu 
(FMC) tergerak untuk mensosialisasikan kepada masyarakat tentang covid-19. Forum mahasiswa cariu pun ikut menggalang dana dari tanggal 25 April 2020 sampai 5 Mei 2020 terkumpul Rp 9.700.000,00. Uang tersebut digunakan untuk pembelian masker, handsanitizer dan sembako bagi masyarakat yang membutuhkan. Pembagian masker dan handsanitizer dilakukan di tempat-tempat yang strategis. Pembagian tersebut dilakukan dibeberapa titik diantaranya pasar, alun-alun dan terminal. Sosialisasi yang dilakukan forum mahasiswa cariu dilakukan disetiap RT dengan dibentuk setiap delegasi mahasiswa.

Dengan memberikan informasi terkait covid-19 dan cara mencegahnya banyak masyarakat yang antusias dalam sosialisasi tersebut. Forum mahasiswa cariu pun dibantu pihak puskesmas kecamatan Cariu dalam mensosialisasikan terkait covid-19. Tindakan bersama ini merupakan wujud nyata rasa kepedulian masyarakat terhadap permasalahan yang ada. Sehingga terdorong untuk melakukan Tindakan Bersama dalam menanggulangi covid-19.

Forum mahasiswa cariu dan juga kominte nasional pemuda Indonesia kecamatan Cariu (KNPI) melaksanakan program membuat tendon air untuk mencuci tangan di tempat yang strategis seperti di pasar, alun-alun dan terminal. Program tersebut agar masyarakat terbiasa dalam pola hidup sehat dan tercegah dari wabah covid-19. Ada 13 tendon air yang ditempatkan ditempat strategis tersebut. Forum mahasiswa cariu juga bekerjasama dengan puskesmas membuat handsanitizer dari daun sirih.

Tindakan kolektif yang dilakukan forum mahasiswa cariu melakukan penyemprotan desinfektan disetiap rumah, masjid dan pasar untuk menghindari penyebaran covid-19. Ini dilakukan serentak dibantu dengan masyarakat desa cariu. Penyemprotan desinfektan tersebut dibimbing langsung pihak puskesmas kecamatan cariu dan dibantu juga dengan koramil kecamatan Cariu. Sehingga banyak element masyarakat terlibat dalam penyemprotan desinfektan untuk mencegah penyebaran covid-19.

\section{Aspek Ekonomi}

Dari aspek ekonomi banyak masyarakat yang mengeluhkan adanya program pembatasan sosial berskala besar (PSBB). Ini yang membuat ekonomi masyarakat menurun. Kabupaten Bogor melaksanakan program PSBB tahap 1 pada 29 April 2020 sampai 12 Mei 2020, dipepanjang Kembali hingga lebaran. Banyak masyarakat mengeluhkan ekonomi menurut terkhusus supir angkot, ojek online, pedagang kaki lima dan buruh harian.

Tindakan kolektif yang dilakukan oleh masyarakat cariu dalam forum mahasiswa cariu tergerak dalam permasalahan tersebut. Penggalangan dana yang dilakukan forum mahasiswa cariu tersebut Sebagian besar dialokasikan untuk membeli kebutuhan pokok yang dibutuhkan masyarakat cariu. Dalam wawancara dengan ketua forum mahasiswa cariu, dikatakan bahwa sekitar $450 \mathrm{kk}$ di desa Cariu yang sangat membutuhkan bantuan sosial yang sifatnya jangka pendek karena dampak covid-19. Bantuan tersebut disalurkan secara langsung oleh forum mahasiswa cariu kepada masyarakat yang membutuhkan.

Disamping bantuan dari pemerintah pusat yang belum juga datang, pemerintah desa membuat program "tengok tetangga". Didalam program tersebut masyarakat diminta untuk saling membantu tetangganya yang membutuhkan. Ini membuat meningkatkan empaty masyarakat dalam kondisi krisis ditengah wabah covid-19. Program ini berjalan dengan baik dalam minggu pertama dapat dilihat banyak masyarakat bergotong royong membantu masyarakat yang sangat membutuhkan bahan pokok seperti beras dan lauk pauk. 
Dari hasil rempug warga masyarakat RT 19 RW 07 desa Cariu melakukan Tindakan kolektif dengan menggarap tanah kosong dan tanah wakaf dari masyarakat untuk ditanami padi, singkong dan jangung. Masyarakat bergotong royong dalam mengolah tanah wakaf tersebut. Hasil panen dari itu peruntukan untuk masyarakat yang sangat membutuhkan. Bukan hanya tanah wakaf, ada juga masyarakat menghibahkan empang ikan untuk menanam benih ikan yang nanti hasilnya dimanfaatkan untuk masyarakat yang membutuhkan.

Ketua DKM masjid al huda kp. Tegal Batu melakukan rapat dengan masyarakat terkait dana renopasi masjid yang dialihkan seperempatnya untuk membantu masyarakat kp. Tegal Batu dalam memenuhi kebutuhan. Tindakan kolektif tersebut dalam upaya membantu masyarakat dalam ekonomi. Akan tetapi masih banyak penunggang gelap dalam kebijakan tersebut. Ada Sebagian masyarakat yang memanfaatkan bantuan tersebut untuk kebutuhan.

\section{Aspek Sosial}

Banyak masyarakat melakukan tindakan kolektif dengan memberikan bantuan langsung kepada masyarakat yang membutuhkan. Melalui forum mahasiswa cariu banyak masyarakat memberikan bantuan terkumpul Rp 9.700.000,00 hanya dalam waku 10 hari. Pembatasan sosial bersekala besar membuat pola masyarakat berubah dalam waktu singkat, yang tadinya pasca lebaran bersilaturahmi dengan keluarga, pada saat ini hanya melalui media sosial saja. Pelaksanaan solat idul fitri pun dilakukan dengan protocol Kesehatan yang ketat dengan menyiapkan thermometer infrared yang disediakan desa Cariu. Pelaksanaan solat pun di lakukan dengan berjaga jarak dan wajib menggunakan masker. Ini diluar dari kebiasaan solat idul fitri pada umumnya.

Dari hasil rapat DKM masjid al Falah zakat fitrah yang terkumpul dari masyarakat itu disalurkan bukan hanya pada mustahiq (orang yang berhak menerima zakat) saja, akan tetapi ada kelompok baru yang terdampak covid-19 yaitu mereka yang sama sekali tidak dapat pemasukan perharinya. Tindakan kolektif ini sangat dibutuhkan dalam wabah seperti ini. Fleksibilitas agama dalam wabah covid-19 sangat dibutuhkan sehingga dampak dari covid-19 harus segera ditanggulangi. Dari hasil zakat tersebut banyak masyarak yang tertolong dalam memenuhi kebutuhan pokoknya. Sehingga dapat mengurangi kesenjangan sosial yang ada di kecamatan Cariu kabupaten Bogor.

\section{Simpulan}

Collective action adalah penyediaan barang public oleh suatu kelompok, karena jika hanya individu-individu saja tidak memiliki kekuatan sosial dalam menyelesaikan permasalahan. Pada kasus pandemi covid-19 banyak masyarakat terdampak pada aspek ekonomi, sosial dan Kesehatan. Tindakan kolektif yang dilakukan masyarakat kecamatan cariu seperti kelompok forum mahasiswa cariu, KNPI kecamatan Cariu dan pihak desa dalam penanggulangan dampak covid-19.

Dari aspek Kesehatan Tindakan yang dilakukan dalam presfektif collective action berupa membagikan masker, handsanitaizer dan bantuan sosial. Lalu tindakan kolektif selanjutnya yaitu menyemprotkan secara serentak dengan desinfektan di titik-titik yang stratgis. Dari aspek ekonomi Tindakan kolektif yang dilakukan masyarakat dengan memberikan bantuan sosial kepada yang terdampak, lalu memberikan solusi dengan menggarap tanah wakaf dan empang ikan hibah masyarakat untuk di garap yang hasilnya akan diberikan kepada masyarakat yang membutuhkan. Dari aspek sosial Tindakan kolektif yang dilakukan dengan menggunakan hasil zakat fitrah untuk kelompok mustahiq (orang yang 
berhak menerima zakat) ditambahkan dengan memberi kepada kelompok baru yaitu masyarakat dengan penghasilan harian yang terdampak covid-19.

Collective action modal utamanya adalah modal sosial. Tanpa modal sosial yang kuat collective action tidak akan berjalan dengan baik, sebaliknya jika modal sosial kuat maka collective action akan berjalan dengan baik. Collective action juga modalnya adalah norma dan empaty yang tumbuh dimasyarakat. Sehingga norma dan empaty harus tumbuh ditengah masyarakat.

\section{Referensi}

Covid-, S. M. P. (2020). Jaminan Hak Kesehatan Pekerja Work From Office. 4, 57-62.

Foys, B. (2014). The logic of collective action. In Economist (United Kingdom) (Vol. 410, Issue 8872). https://doi.org/10.4337/9781843763017.00013

Jasper, James M., 1997. The Art of Moral Protest, Culture, Biography andCreativity in Social Movement. Chicago: The University of Chicago Press

Olson, Mancur. 1965. The Logic of Collective Action: Public Goods and the Theory of Groups. Harvard: Cambridge.

Tajfel, H. \& Turner, J. C. 1986. The Social Identitiy Theory of Intergroup Behavior dalam S. Warchel \& W. G. Austin (Eds.). Psichology of Intergroup Relations, pp. 7-29. Nelson Hall:Chicago.

Tilly, Louise A dan Charles Tilly (eds), Class Conflict and Collection Action, Baverly Hills: Sage. 1981,

Willer, R. (2009). A status theory of collective action. Advances in Group Processes, 26(September 2009), 133-163. https://doi.org/10.1108/S0882-6145(2009)0000026009

Wright, S., Taylor, D. M., \& Moghaddam F.M. 1990. Responding Membership in a Disadvantaged Group: From Acceptance to Collective Protest. Journal of Personalitiy and Social Psychology,Vol 54, No. 6, pp. 994-1003. 